${ }^{5}$ McMaster KR III, Hennigar GR. Drug-induced granulomatous hepatitis. Lab Invest $1981 ; 44: 61-73$.

${ }^{6}$ Cunningham D, Mills PR, Quigley EMM, et al. Hepatic granulomas experience over a 10-year period in the West of Scotland. $Q \mathcal{F ~} \mathrm{Med}$ $1982 ; 51$ (NS): $162-70$

${ }^{7}$ Lee RG, Epstein O, Jauregui H, Sherlock S, Scheuer PJ. Granulomas in primary biliary cirrhosis: a prognostic feature. Gastroenterology 1981 81 :983-6.

${ }^{8}$ Torres-Salinas M, Bruguera M, Cabrera J, Rodés J. Hepatitis por fiebre Q Gastroenterologia y Hepatologia 1978;1:230-2.

9 Pellegrin M, Delsol G, Auvergnat JC, et al. Granulomatous hepatitis in $\mathrm{Q}$ fever. Hum Pathol 1980;11:51-7.

${ }^{10}$ Simon HB, Wolff SM. Granulomatous hepatitis and prolonged fever of unknown origin: a study of 13 patients. Medicine (Baltimore) 1973;52 $1-21$.

11 Litwack KD, Bohan A, Silverman L. Granulomatous liver disease and gian cell arteritis. Case report and literature review. $\mathcal{F}$ Rheumatol 1977;4: 307-12.

\section{Blood donors with a history of jaundice}

Up till 1975 people with a history of jaundice were not acceptable as blood donors. The recommendation that this policy should be changed was made by an advisory group on testing for the presence of hepatitis B surface antigen ( $\mathrm{HBsAg}$; the "Australia" antigen) and its antibody." The group's recommendation was that potential donors should no longer be excluded provided that their blood did not contain detectable HBsAg and that they "had not suffered from hepatitis or jaundice during the previous 12 months."

In 1979 the group was reconvened to consider any changes in policy that might be desirable in the light of advances in knowledge, and its report appeared in 1981.2 Techniques for detecting HBsAg and its associated viral antigens and antibodies have improved rapidly, enzyme-linked immunoassay and radioimmunoassay taking the place of counterimmunoelectrophoresis and reverse passive haemagglutination. As a result, progressively fewer $\mathrm{HBsAg}$-positive donations have been found, most positive donors being rejected early. Regional transfusion centres in Britain now find between one in 500 and one in 1000 new donors to be $\mathrm{HBsAg}$ positive with an overall incidence of about one in 4000 in the donor population as a whole. Yet despite the increased rate of detection not all carriers can be identified, and $\mathrm{HBsAg}$-positive hepatitis (hepatitis B) still remains a hazard of blood transfusion.

The sensitivity of the method of testing is especially important for the use of some plasma products, rather than whole blood or packed cells. The products manufactured for treating the haemophilias, factor VIII and IX concentrates, are prepared from up to 5000 plasma donations, and the risk of contamination of these large pools is high. As a result the group has recommended that only the most sensitive techniques should be employed for all plasma donations sent for fractionation. The major difficulty in attempts to eliminate post-transfusion hepatitis, however, remains the absence of markers for the non-A, non-B viruses. So, though increased sensitivity of donor screening (together with the prospects ${ }^{3}$ for immunisation of at-risk groups) will virtually, but not completely, remove the threat of HBsAg-positive disease, the diagnosis of non-A, non-B hepatitis remains non-specific, and its true incidence remains unknown. Experience with haemophiliacs suggests that the non- $A$, non-B infection is often subicteric, presenting as a short incubation influenza-like illness, and diagnosed correctly only by maintaining a high level of suspicion and finding disordered liver function values. Because of this the extent and severity of post-transfusion hepatitis due to non- $A$, non-B viral infection have yet to be determined, though it is thought to account for $90 \%$ of all such cases in the United States. ${ }^{4}$ The diagnosis is important, because non-A, non-B infection may progress to chronic liver disease.

In Australia the only measures used to prevent posttransfusion hepatitis are the exclusion of donors jaundiced in the past two years and those whose donations are $\mathrm{HBsAg}$ positive on radioimmunoassay, and Cossart et $a l^{5}$ have recently reported the development of hepatitis in 18 of 842 patients undergoing cardiac surgery. Three infections were caused by hepatitis $\mathrm{B}$, one by cytomegalovirus, and 14 by probable non- $A$, non- $B$ viruses. The authors found a correlation between the non- $A$, non- $B$ infections and the presence of antibodies against hepatitis $B$ core antigen ( $\mathrm{HBcAg}$ ) and $\mathrm{HBsAg}$ in the donor blood but concluded that only about half the non-A, non-B infections might be avoided if routine surveillance for these markers was introduced. Aach and $\mathrm{Kahn}^{4}$ have suggested that screening of liver function, specifically by measuring alanine transaminase activity, would help eliminate some non-A, non-B infective donors.

Probably, then, the incidence of non- $A$, non- $B$ infection might be reduced by routine testing for antibodies against $\mathrm{HBcAg}$ and HBsAg and measuring alanine transaminase activity, but on present evidence about half the infective donations would still pass scrutiny. From the donor viewpoint the additional tests would be both expensive and time consuming. In Britain the risk implied in accepting donors with a history of jaundice is minor. But what of the recipient? From his viewpoint the present risk of developing disordered liver function after transfusion of volunteer $\mathrm{HBsAg}$-negative blood is about $10 \%,{ }^{6}$ and the risks rise with the number of donations he receives. Most of the experts at a recent international forum ${ }^{8}$ thought that this risk was unacceptable. Their conclusion was that donors with a history of jaundice (some $0.5 \%$ of the donor population ${ }^{6}$ ) should continue to be excluded.

British policy differs from this view, but the advisory group has recommended that doctors should be encouraged to report all cases of post-transfusion jaundice. Where these might be due to non-A, non-B hepatitis, the facts should be reported to the appropriate advisers in blood transfusion at the DHSS or Scottish Home and Health Department. ${ }^{2}$

Peter M Jones

Consultant Paediatrician,

Newcastle Haemophilia Centre,

Royal Victoria Infirmary,

Newcastle upon Tyne NE1 4LP

1 Advisory Group on Testing for the Presence of Hepatitis B Surface Antigen and its Antibody. Second report. London: DHSS, 1975.

2 Advisory Group on Testing for the Presence of Hepatitis B Surface Antigen and its Antibody. Third report. London: DHSS, 1981.

3 Zuckerman AJ. Priorities for immunisation against hepatitis B. Br Med $\mathfrak{F}$ 1982;284:686-8.

4 Aach RD, Kahn RA. Post-transfusion hepatitis: current perspectives. Ann Intern Med 1980;92:539-46.

5 Cossart YE, Kirsch S, Ismay SL. Post-transfusion hepatitis in Australia. Report of the Australian Red Cross Study. Lancet 1982;i:208-13.

${ }^{6}$ Alter HJ. Should donors with a history of jaundice still be rejected? Vox Sang $1981 ; 41: 112-3$.

7 Seef LB. Post-transfusion hepatitis. In: Seligsohn U, Horoszowski H, Rimon A, eds. Haemophilia. Tunbridge Wells : Castle House Publications, 1980:131-9.

${ }^{8}$ Anonymous. Should donors with a history of jaundice still be rejected ? Vox Sang 1981;41:110-27. 